JURNAL PENDIDIKAN, p-ISSN 2715-095X, e-ISSN 2686-5041

Volume 30, No.3, Nopember 2021 (463-470)

Online: http://journal.univetbantara.ac.id/index.php/jp

\title{
Upaya Meningkatkan Motivasi Belajar Siswa Melalui Layanan Bimbingan Kelompok dengan Menggunakan Teknik Diskusi pada Siswa Kelas VIII A SMP Negeri 4 Sukoharjo Tahun Pelajaran 2017/ 2018
}

\begin{abstract}
Sri Suprapti
SMP Negeri 4 Sukoharjo, E-mail:srisuprapti@gmail.com

Received: Juli 08, 2021

Accepted: Oktober 24, 2021

Online Published: Nopember 08, 2021

Abstrak: Tujuan dalam penelitian ini untuk meningkatkan motivasi belajar siswa melalui bimbingan kelompok dengan teknik diskusi pada kelas VIII A SMP Negeri 4 Sukoharjo tahun pelajaran 2017/ 2018. Desain penelitian ini menggunakan penelitian tindakan kelas. Setiap siklus terdiri dari 4 tahapan yaitu perencanaan, tindakan, observasi dan refleksi.Subjek pada penelitian ini adalah siswa kelas VIII A SMP Negeri 4 Sukoharjo tahun pelajaran 2017/ 2018 sebanyak 6 siswa. Metode pengumpulan data yang digunakan dalam penelitian ini adalah data yang diperoleh dianalisis melalui tahapan-tahapan perencanaan, pelaksanaan tindakan, pengamatan, evaluasi, dan refleksi. Untuk menjaga objektivitas data hasil observasi dengan menggunakan teknik triangulasi. Data yang diperoleh dianalisis melalui tahapan-tahapan observasi dan perencanaan, refleksi tindakan, monitoring penelitian, refleksi hasil penelitian dan pengembangan. Hasil penelitian tindakan kelas diperoleh nilai mean motivasi belajar pada prasiklus sebesar 51,56 \%. Pada siklus I diperoleh mean sebesar 61,45\% dan siklus II diperoleh mean sebesar $85,41 \%$. Berdasakan hasil penelitian menunjukkan siswa mulai menyadari pentingnya motivasi belajar. Hal ini dapat dilihat siswa yang mulai bersemangat mengikuti kegiatan belajar di sekolah. Uraian hasil penelitiantersebut dapat disimpulkanbahwa telah terjadi peningkatan motivasi belajar siswa melalui layanan bimbingan kelompok dengan teknik diskusi.
\end{abstract}

Kata-kata Kunci: motivasi belajar siswa, layanan bimbingan kelompok teknik diskusi.

\section{Improving Students Learning Motivation Through Group Counceling Service Using Discussion Technique In The Eighth Grade Students of SMPN 4 Sukoharjo In 2017/2018 Academic Year}

\author{
Sri Suprapti \\ SMP Negeri 4 Sukoharjo, E-mail:srisuprapti@gmail.com
}

\begin{abstract}
The aim of this research is to improve students learning motivation through group counceling service using discussion technique in the eighth grade students of smp $n 4$ skh in 2017/2018 academic year. This research is designed using classroom action research. Every cycle has 4 steps, that are planning, action, observation and reflection. The subjects of this research are 6 students in $8 \mathrm{~A}$ of smp $n 4$ skh in 2017/2018 academic year. The data collection method using in this research is the data is analyzed steps of planning, action, observation and reflection. To maintain the objectivity, the data observation result uses triangulation technique. The data is analyzed steps of observation and planning, reflection of action, research monitoring, research result reflection and development. The result of this classroom action research of the average of students learning motivation in the pre-cycle is $51,56 \%$. The average in cycle 1 is $61,45 \%$ and the average in cycle 2 is 85,41\%. This research shows that the students start to realize the importance of learning motivation. This can be seen from the
\end{abstract}


students who feel enthusiastic in following learning activity in school. From the explanation of research result can be concluded that there is improvement of students learning motivation through group counceling service using discussion technique.

Keywords: students learning motivation, group counceling service using discussion technique

\section{Pendahuluan}

Pembangunan Nasional di bidang sumber daya manusia Indonesia yang berkualitas melalui pendidikan merupakan upaya yang sungguh-sungguh dan terus-menerus dilakukan untuk mewujudkan manusia Indonesia seutuhnya. Sumber daya yang berkualitas akan menentukan mutu kehidupan pribadi, masyarakat, dan bangsa dalam rangka mengantisipasi, mengatasi persoalan-persoalan, dan tantangan-tantangan yang terjadi dalam masyarakat pada kini dan masa depan. Untuk mewujudkan maksud di atas bukan hal yang mudah dan sederhana. Membutuhkan waktu yang lama dan memerlukan dukungan seluruh komponen bangsa dan usaha yang direncanakan secara matang, berkelanjutan serta berlangsung seumur hidup. Upaya meningkatkan kualitas pendidikan di Indonesia tidak pernah berhenti (Suwarto, 2013, 2017). Berbagai terobosan baruterus dilakukan oleh pemerintah melalui Kementerian Pendidikan. Upaya itu antara lain dalam pengelolaan sekolah, peningkatan sumber daya tenaga pendidikan, pengembangan/penulisan materi ajar, serta pengembangan paradigma baru dengan metodologi pengajaran. Mengajar bukan semata persoalan menceritakan. Belajar bukanlah konsekuensi otomatis dari perenungan informasi ke dalam benak siswa.Belajar memerlukan keterlibatan mental dan kerja siswa sendiri. Penjelasan dan pemeragaan semata tidak akan membuahkan hasil belajar yang langgeng. Membuahkan hasil belajar yang langgeng tersebuthanyalah kegiatan belajar secara aktif. Dalam suatu forum diskusi guru $\mathrm{BP} / \mathrm{BK}$ sering menemukan kesulitan membelajarkan siswa agar mempunyai motivasi belajar yang tinggi.Motivasi belajar anak dalam kegiatan sangat penting bagi pembelajaran.Oleh karena itu, motivasi belajar perlu dimiliki, termasuk siswa SMP Negeri 4 Sukoharjo. Jika ingin siswa mempunyai prestasi belajar yang tinggi, makasiswa memerlukan motivasi atau dorongan dalam belajar, karena motivasi adalah hal penting dalam belajar.

Prestasi merupakan puncak dari hasil belajar.Prestasi belajar menurut Pratiwi (2015) adalah perubahan yang diperoleh siswa setelah mengalami proses pembelajaran untuk mencapai tujuan pembelajaran yang diwujudkan dalam bentuk perbuatan. Pada tahap ini siswa membuktikan keberhasilan belajarnya. Faktor yang mempengaruhi prestasi belajar siswa tidak hanya dari orang tua ataupun orang terdekatnya.Tetapi, diperlukan juga motivasi dari dalam siswa itu sendiri. Tak jarang siswa memiliki nilai yang kurang bagus di sekolahnya karena mereka tidak memiliki motivasi yang membuat mereka semangat untuk belajar. Mereka alami hanyalah diberi uang saku oleh orang tua, lalu pergi sekolah tanpa menyadari tujuan siswa bersekolah. Adapun pengertian motivasi adalah daya penggerak di dalam diri seseorang untuk melakukan aktivitas-aktivitas tertentu demi mencapai sebuah tujuan (W.S Winkel, 2000:45).Untuk meningkatkan motivasi siswa tidak hanya dilakukan oleh orang tuanya saja, namun juga diwujudkan melalui bimbingan belajar kelompok yang 
dilaksanakan di sekolah juga.Adapun maksud dari layanan bimbingan kelompok adalah suatu kegiatan layanan bimbingan konseling yang diberikan kepada siswa yang terdiri maksimal 10 orang dimana semua anggota saling berinteraksi membahas topik-topik yang sifatnya umum dan merupakan kegiatan yang memiliki fungsi pengembangan. Sedangkan teknik diskusi adalah suatu cara dimana siswa memperoleh kesempatan untuk memecahkan masalah secara bersama-sama dengan saling mengemukakan pikirannya masing-masing.

Motivasi adalah gaya penggerak di dalam diri seseorang untuk melakukan aktivitasaktivitas tertentu demi mencapai sebuah tujuan (W.S Winkel, 2000:45). Sedangkan pengertian belajar sendiri adalah perubahan dalam pribadi yang menyatakan diri sebagai pola baru dari pada reaksi yang merupakan kecakapan, sikap/kebiasaan, kepandaian/suatu pengabdian (Purwanto, 2001:86). Jadi, motivasi belajar merupakan suatu daya penggerak pada diri seseorang untuk mendorong diri sendiri agar lebih bersemangat dalam berprestasi.

Motivasi sangat penting artinya dalam kegiatan belajar, sebab adanya motivasi maka akan mendorong semangat belajar dan sebaliknya jika kurang adanya motivasi akan melemahkan semangat belajar. Motivasi merupakan syarat mutlak dalam belajar; seorang siswa yang belajar tanpa motivasi (atau kurang motivasi) tidak akan berhasil dengan maksimal.

Menurut Mc. Donald (dalam Sardiman A.M, 2011:73) motivasi adalah perubahan energi dalam diri seseorang yang ditandai dengan munculnya "feeling" dan didahului dengan tanggapan terhadap adanya tujuan. Graham \& Golan (1991:78) menyatakan bahwa: Motivasi penting dalam menentukan seberapa banyak siswa yang akan belajar dari suatu kegiatan pembelajaran atau seberapa banyak menyerap informasi yang disajikan kepada mereka. Siswa yang termotivasi untuk belajar sesuatu akan menggunakan proses kognitif yang lebih tinggi dalam mempelajari materi itu, sehingga siswa itu akan menyerap dan mengendapkan materi itu dengan lebih baik. Sedangakan, motivasimenurut Muhammad (2016) adalah sesuatu perubahan tenaga di dalam diri/pribadi seseorang yang ditandai oleh dorongan dan reaksireaksi usaha untuk mencapai tujuan dalam memenuhi kebutuhannya.

Motivasi belajar siswa merupakan faktor utama yang menentukan keberhasilan belajarnya. Kadar motivasi ini banyak ditentukan oleh kadar kebermaknaan bahan pelajaran dan kegiatan pembelajarannya yang dimiliki oleh siswa yang bersangkutan (Djamarah S.B. dkk,1995:70). Menurut Suharni dan Purwanti (2018) sebagai guru atau calon guru sebisa mungkin kita harusselalu berupaya untuk dapat meningkatkan motivasi belajar terutama bagi siswa yang mengalami kesulitan dalam belajar dengan menggunakan berbagai upaya yang dapat dilakukan oleh guru yaitu 1) Memperjelas tujuan yang ingin dicapai. 2) Membangkitkan motivasi siswa. 3) Ciptakan suasana yang menyenangkan dalam belajar. 4)Mengguanakan variasi metode penyajian yang menarik. 5)xddBerilah pujian yang wajar setiap keberhasilan siswa. 6) Berikan penilaian. 7) Berilah komentar terhadap hasil pekerjaan siswa. 8) Ciptakan persaingan dan kerjasama. Penulis dapat menyimpulkan bahwa motivasi belajar adalah proses internal yang merupakan salah satu faktor utama yang membentuk tingkat keberhasilan belajar siswa.

Bimbingan kelompok dapat diartikan secara sederhana dan secara mendalam. Secara sederhana, bimbingan kelompok, diartikan sebagai bimbingan yang diberikan kepada sekelompok individu yang mengalami masalah yang sama. Pada pengertian secara mendalam, bimbingan kelompok adalah bimbingan yang diberikan kepada sejumlah individu dengan memanfaatkan dinamika kelompok (Amti, 1993:105). Menurut Gazda dalam Prayitno dan Amti (1999:309) mengemukakan bahwa bimbingan kelompok di 
sekolah merupakan kegiatan informasi kepada sekelompok siswa untuk membantu mereka menyusun rencana dan keputusan yang tepat. Dengan kata lain, bimbingan kelompok diberikan kepada siswa dengan tujuan untuk membantu siswa dalam menata rencana kehidupannya agar tidak salah dalam bertindak dan mengambil keputusan.

Alamri (2015) berpendapatbahwalayanan bimbingan kelompok merupakanlayanan bimbingan yang dilaksanakan didalam suasana kelompok. Pada pelaksanaan bimbingan kelompok ada konselor, yaitu Konselor, dan anggota kelompok yaitu klien (yang jumlahnyalebih dari satu orang). Motivasi belajar anak melalui bimbingan kelompok sangat diperlukan, agar dalam bimbingan kelompok tersebut menjadi hidup, menjadi semangat dan masalah yang diungkapkan dapat terpecahkan dan terselesaikan. Diskusi kelompok merupakan suatu cara dimana murid-murid akan mendapat kesempatan untuk memecahkan masalah bersama-sama. Setiap murid dapat menyumbangkan pikiran masing-masing dalam memecahkan suatu masalah.Dalam diskusi itu dapat tertanam pula rasa tanggung jawab dan harga diri. Bentuk-bentuk teknik bimbingan kelompok ini guru BK menggunakan bentuk diskusi kelompok. Komponen-komponen yang ada dalam layanan bimbingan kelompok diantaranya terdapat pemimpin kelompok dan anggota kelompok Prayitno (1995:35-36). Berdasarkan uraian di atas, maka penulis merumuskan masalah sebagai berikut: "Apakah motivasi belajar siswa dapat ditingkatkan melalui bimbingan kelompok menggunakan teknik diskusi pada siswa kelas VIII A SMP Negeri 4 Sukoharjo semester I tahun pelajaran 2017/ 2018?".

\section{Metode Penelitian}

Penelitian ini merupakan penelitian tindakan bimbingan konseling (PTBK) yang dilakukan melalui proses kolaborasi antara guru BK, kepala sekolah dan guru BK lain atau teman sejawat dan merupakan aplikasi penelitian tindakan kelas (PTK) dalam layanan BK di sekolah. SuharsimiArikunto (2007:3) penelitian tindakan kelas adalah suatu pencermatan terhadap kegiatan belajar berupa sebuah tindakan yang sengaja dimunculkan dan terjadi dalam sebuah kelas secara bersama.Tindakan tersebut diberikan oleh guru atau dengan arahan dari guru yang dilakukan oleh siswa. Tempat penelitian ini dilaksanakan di SMP Negeri 4 Sukoharjo. Subjek penelitian adalah siswa kelas VIII A SMP Negeri 4 Sukoharjo Tahun Pelajaran 2017/2018. Subjek penelitian dalam penulisan PTBK ini adalah 6 orang siswa kelas VIII A SMP Negeri 4 Sukoharjo, terdiri dari 4 orang siswa laki-laki dan 2 siswa perempuan yang mempunyai motivasi belajar rendah, kemudian akan dibentuk menjadi sebuah kelompok.

Sesuai dengan bentuk penelitian tindakan dalam bimbingan dan konseling, juga sumber data yang dimanfaatkan, maka teknik pengumpulan data menggunakan teknis observasi. Observasi ini dilakukan untuk mengamati secara langsung proses pelaksanaan bimbingan kelompok yang diperlukan untuk menata langkah-langkah perbaikan agar lebih efektif dan efisien. Observasi dipusatkan pada proses dan hasil tindakan bimbingan kelompok beserta peristiwa-peristiwa yang melingkupinya. Teknik pengujian validitas yang dipergunakan yaitu teknik trianggulasi. Adapun yang digunakan guru BP/ BK adalah trianggulasi data (sumber) yaitu mengumpulkan data yang sejenis dari sumber data yang 
berbeda. Sumber data dalam penelitian ini adalah: siswa, hasil pengamatan kegiatan diskusi kelompok dan guru. Analisis data menggunakan metode statistik dengan teknik prosentase. Indikator kinerja dalam penelitian ini adalah adanya peningkatan rata-rata presentase skor motivasi belajar siswa kelas VIII A SMP Negeri 4 Sukoharjo Tahun Pelajaran 2017/ 2018 sebesar $80 \%$.

\section{Hasil Penelitian}

Sebelum melakukan penelitian, guru BK mengadakan persiapan penelitian agar hasil yang dicapai dapat maksimal. Berdasarkan pelaksanaan tindakan ini, guru BK menganalisis data yang diperoleh selama proses penelitian berlangsung, yakni bagai meningkatkan motivasi belajar siswa di dalam kelas pada siswa kelas VIII A SMP Negeri 4 Sukoharjo dengan penerapan bimbingan kelompok teknik diskusi. Hasil observasi sebelum diadakan, tindakan guru BK melakukan wawancara wali kelas VIII A, serta melihat data dari informasi-informasi yang diperoleh dari guru-guru mata pelajaran bahwa pada kelas tersebut terdapat beberapa siswa yang mempunyai motivasi belajar yang rendah. Sebagai subjek penelitian adalah siswa kelas VIII A SMP Negeri 4 Sukoharjo yang berjumlah 32 siswa.

Tahap prasiklus ini guru BK melihat bagaimana proses belajar mengajar secara langsung di kelas VIII A SMP Negeri 4 Sukoharjo. Dalam pembelajaran tersebut belum menggunakan model bimbingan kelompok secara aktif dan masih menggunakan metode format klasikal/ceramah yang siswanya masih belum banyak berpartisipasi aktif dalam proses pembelajaran dan cenderung terjadi komunikasi yang pasif. Di saat KBM berlangsung guru BK mengamati peserta didik untuk mengetahui seberapa besar tingkat motivasi belajar siswa di dalam kelas. Lima siswa tersebut memiliki presentase nilai ratarata 50,45\%, dari data ini menunjukkan motivasi belajar siswa kelas VIII A SMP 4 Sukoharjo belum mencapai batas tuntas yang ditetapkan, yaitu mencapai persentase nilai 80\%. Dengan demikian, pada kondisi awal motivasi belajar siswa dapat dikatakan belum mencapai tujuan yang diharapkan.

Berdasarkan motivasi belajar siswa yang masih rendah tersebut, maka guru BK menerapkan bentuk layanan bimbingan kelompok dengan teknik diskusi untuk meningkatkan motivasi belajar siswa. Berdasarkan hasil pengamatan yang telah dilakukan peneliti, menunjukkan adanya perbedaan motivasi belajar siswa di dalam kelas dari ketujuh siswa kelas VIII A SMP Negeri 4 Sukoharjo sebelum mendapat bimbingan kelompok dengan sesudah mendapat bimbingan kelompok tersebut. Hasil penelitian menunjukkan bahwa rata-rata motivasi belajar siswa di dalam kelas dapat dinyatakan meningkat dibandingkan sebelum dan sesudah diberikan layanan bimbingan kelompok dengan menggunakan teknik diskusi.

Berdasarkan pengamatan tampak terlihat jelas dari kedua siklus tersebut selalu mengalami peningkatan motivasi belajar yang dimulai dari siklus I kemudian mencapai target indikator keberhasilan yang diinginkan guru BK pada siklus II yang dapat dilihat pada tabel berikut:

Tabel 1. Perbandingan Jumlah Skor dan Persentase Motivasi Belajar Siswa pada Tahap Pra-Siklus, Siklus I dan Siklus II

\begin{tabular}{llccc}
\hline \multirow{2}{*}{ No } & \multirow{2}{*}{ Nama Siswa } & \multicolumn{3}{c}{ Presentase (\%) } \\
\cline { 2 - 4 } & & Pra Siklus & Siklus I & Siklus II \\
\hline
\end{tabular}




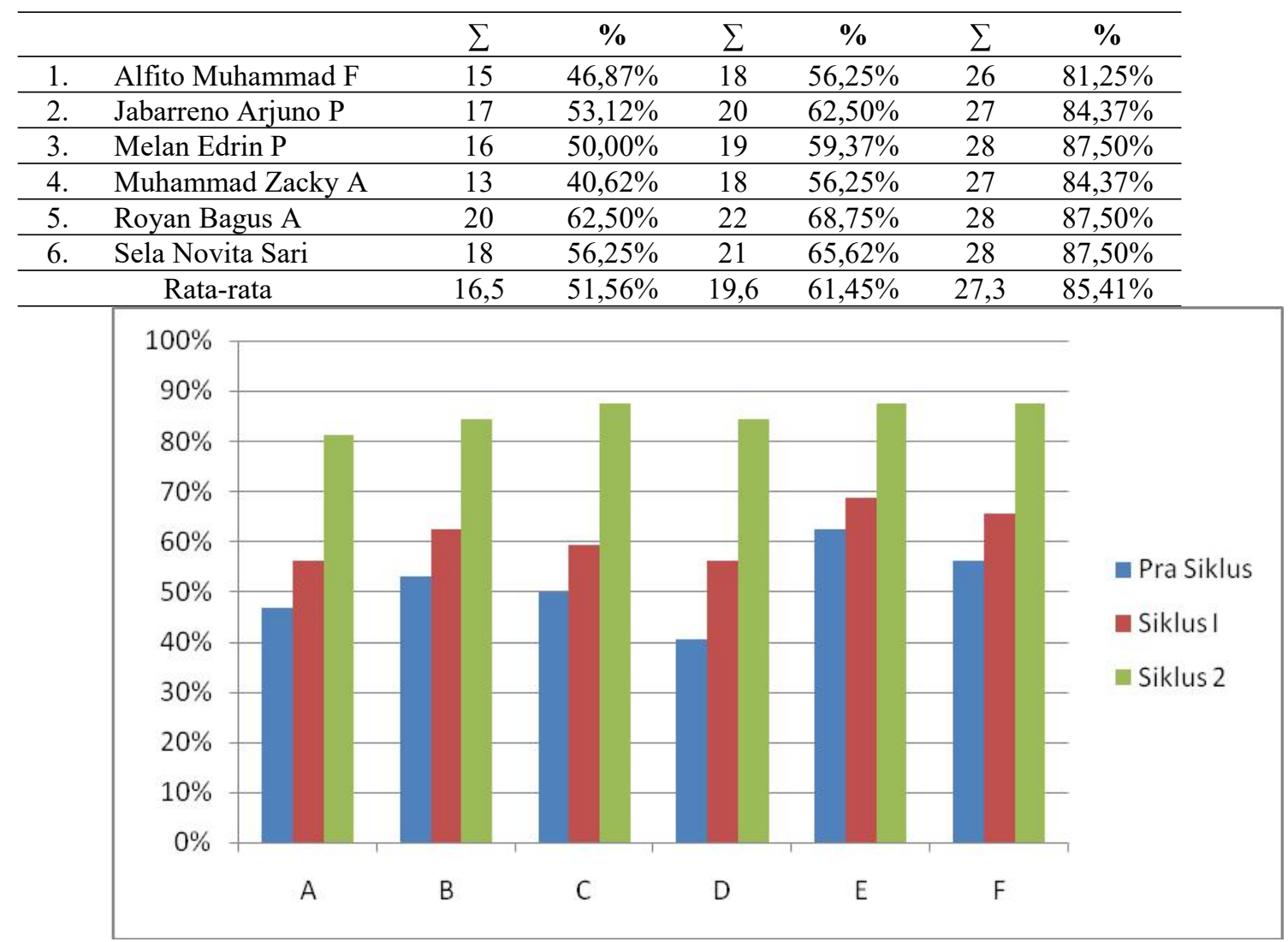

Gambar 1 Grafik Perbandingan Jumlah Skor dan Persentase Motivasi Belajar Siswa

Berdasarkan data awal atau pra tindakan rata-rata presentase nilai motivasi belajar siswa adalah sebesar 51,56\%, setelah dilakukan tindakan bimbingan kelompok dengan teknik diskusi pada siklus I motivasi belajar siswa mengalami peningkatan presentase nilai, yaitu $61,45 \%$ pada siklus I. namun, pada siklus I ini motivasi belajar siswa belum memenuhi indikator kinerja yang ditetapkan, yaitu 80\%. Maka dari itu selanjutnya siswa diberikan bimbingan kelompok teknik diskusi pada siklus II. Pada siklus II ini motivasi belajar siswa menunjukkan peningkatan presentase rata-rata menjadi $85,41 \%$. Dengan demikian hipotesis tindakan bimbingan kelompok efektif untuk meningkatkan motivasi belajar siswa di dalam kelas VIII A SMP Negeri 4 Sukoharjo Tahun Pelajaran 2017/ 2018 diteima keberhasilannya.

\section{Simpulan dan Saran}

Berdasarkan hasil analisis data setelah dilakukan tindakan pada siklus I dan siklus II, maka dapat disimpulkan bahwa melalui bimbingan kelompok dengan teknik diskusi dapat meningkatkan motivasi belajar siswa di sekolah pada siswa kelas VIII A SMP Negeri 4 Sukoharjo Tahun Pelajaran 2017/ 2018. Hal ini ditunjukkan dengan adanya peningkatan 
hasil skor rata-rata dalam observasi motivasi belajar siswa dari kondisi awal pra-siklus $51,56 \%$, siklus I sebesar $61,45 \%$ dan siklus II sebesar 85,41\%.

Berdasarkan hasil penelitian tindakan kelas yang telah dilakukan untuk meningkatkan motivasi belajar siswa di sekolah melalui layanan bimbingan kelompok dengan teknik diskusi, maka terdapat beberapa saran yang diajukan sebagai berikut: (1) Diharapkan guru BK dapat menerapkan bimbingan kelompok dengan teknik diskusi dalam membantu menyelesaikan permasalahan siswa yang berhubungan dengan motivasi belajar siswa dalam proses pembelajaran di sekolah; (2) Siswa diharapkan dapat meningkatkan motivasi belajar serta dapat aktif dalam kegiatan belajar mengajar di sekolah; dan (3) Berusaha melengkapi fasilitas sekolah guna menunjang proses belajar mengajar siswa untuk lebih meningkatkan motivasi belajar siswa di sekolah, serta pihak sekolah harus sering mengikutsertakan guru bimbingan konseling dalam seminar maupun pelatiahnpelatihan psikologi supaya guru bimbingan dan konseling dapat pula menambah pengetahuan serta mampu menerapkannya dalam proses pemberian layanan bimbingan konseling pada peserta didik di SMP Negeri 4 Sukoharjo.

\section{Daftar Rujukan}

Alamri, Nurdjana. (2015). Layanan Bimbingan Kelompok dengan Teknik Self Management untuk Mengurangi Perilaku Terlambat Masuk Sekolah (Studi pada Siswa Kelas X SMA 1 Gebog Tahun 2014/2015). Jurnal Konseling GUSJIGANG Volume 1(1). Diambil dari: https://core.ac.uk/download/pdf/304202254.pdf

Amti E, Prayitno. (1999). Dasar-dasar Bimbingan Konseling. Jakarta: PT. Rineka Cipta.

Chosiyah. (2001). Bimbingan dan Konseling Belajar. Universitas Sebelas Maret Surakarta: Tidak diterbitkan.

Djamarah, S.B dkk. (1995). StrategiBelajarMengajar. Banjarmasil: RinekaCipta.

Endang Sampurnawati. (2017). Upaya Meningkatkan Motivasi Belajar Melalui Bimbingan Kelompok pada Siswa. Skripsi: IKIP Veteran Semarang.

Mochamad Nursalam, Suradi. (2002). Layanan Bimbingan dan Konseling. Surabaya: Unesa University Press.

Muhammad, Maryam. (2016). Pengaruh Motivasi dalam Pembelajaran. Lantanida Journal, Volume 4(2).

https://media.neliti.com/media/publications/287678-pengaruh-motivasi-dalampembelajaran-dc0dd462.pdf

Oemar Hamalik. (2004). Psikologi Belajar dan Mengajar. Bandung: Sinar Baru Algensindo.

Okta Endah Wati. (2016). Penggunaan Layanan Bimbingan Kelompok Untuk Meningkatkan Motivasi Belajar pada Siswa Kelas VIII SMP Negeri 9 Kota Metro Tahun Pelajaran 2015/2016. Skripsi: Universitas Lampung.

Pratiwi, Noor Komari. (2015). Pengaruh Tingkat Pendidikan, Perhatian Orang Tua, danMinat Belajar Siswa terhadap Prestasi Belajar Bahasa

Indonesia Siswa SMK Kesehatan di Kota Tangerang. Jurnal Pujangga, Volume 1(2). https://www.google.com/url? sa $=\mathrm{t} \& \mathrm{rct}=\mathrm{j} \& \mathrm{q}=\&$ esrc $=\mathrm{s} \&$ source $=$ web\& $\mathrm{cd}=\& \mathrm{cad}=\mathrm{rja} \&$ uact=8\&ved=2ahUKEwjB4K 7hxanzAhXhmuYKHeh0B4QQFnoECAYQAQ\&url= http\%3A\%2F\%2Fjournal.unas.ac.id\%2Fpujangga\%2Farticle\%2Fdownload\%2F320 \%2F218\&usg=AOvVaw1JW3KFkcJ2TNEAd5 1VZeu 
Prayitno. (1995). Layanan Bimbingan dan Konseling Kelompok. Jakarta: Rineka Cipta.

Purwanto. (2009). Evaluasi Hasil Belajar. Yoyakarta: Pustaka Pelajar.

Sardiman. (2010). Interaksi dan Motivasi Belajar Mengajar. Jakarta: Bina Aksara.

Slameto. (2003). Belajar dan Faktor-faktor yang Mempengaruhinya. Jakarta: Rineka Cipta. Suhaimin. (2008). Motivasi Belajar. Jakarta: CV. Rajawali.

Suharni \& Purawanti. (2018). Upaya Meningkatkan Motivasi Belajar Siswa. Jurnal Bimbingan dan Konseling, Volume, 3(1).

Suharsimi Arikunto. (2006). Prosedur Penelitian Suatu Tindakan Praktik. Jakarta: Rineka Cipta.

Suwarto, D. (2013). Pengembangan Tes Diagnostik Dalam Pembelajaran. Yogyakarta: Pustaka Pelajar.

Suwarto, S. (2017). Pengembangan tes ilmu pengetahuan alam terkomputerisasi. Jurnal Penelitian dan Evaluasi Pendidikan, 21(2), 153-161.

Winkel. W. S. (1991). Bimbingan dan Konseling di Institut Pendidikan. Jakarta: Gramedia. 